\title{
The adaptation of the pedagogical knowledge and skills survey into Turkish: Validity and reliability study
}

\author{
Tuba Gökçek \\ Kırıkkale University, Kırıkkale, Turkey, tgokcek@gmail.com \\ ORCID:0000-0003-2923-070X \\ Aynur Y1lmaz \\ Trabzon University, Trabzon, Turkey, aynuryilmaz@ktu.edu.tr \\ ORCID: 0000-0001-7562-9469
}

\begin{abstract}
This research aims to adapt the Pedagogical Knowledge and Skills in Teaching (PKST) survey developed by Wong, Chong, Choy and Lim (2012) to Turkish. The participants of the study are 830 4th year students of education faculty studying at two different public universities. Explanatory Factor Analysis (EFA) was conducted with total 205 pre-service teachers in which $110(53.6 \%)$ of female and $95(46,4 \%)$ of male. Confirmatory Factor Analysis (CFA) was also carried out with total 625 preservice teachers in which $330(52.8 \%)$ of them are female, $295(47.2 \%)$ of them are male. Back translation was used to ensure language validity. EFA and CFA were conducted for the construct validity and to ensure psychometric characteristics of measurement tool. EFA show that survey has six factors and 37 items. Coefficient was 0.94 for the survey whereas it ranged between 0.70 and 0.88 for its factors. The analyses and findings show that the survey is a valid and reliable data collection tool.
\end{abstract}

Keywords

Pedagogical knowledge and skills, Pre-service teachers, Reliability, Validity, Survey adaptation

\section{Pedagojik bilgi ve beceri ölçeğinin Türkçe’ye uyarlanması: Geçerlik ve güvenirlik çalışması}

ÖZ Araştırmada Wong, Chong, Choy ve Lim (2012) tarafindan geliștirilerek, geçerlik ve güvenirlik çalışması yapılan öğretmen adaylarının Öğretimde Pedagojik Bilgi ve Beceri (ÖPBB) ölçeğinin Türkçeye uyarlanması amaçlanmıştır. Çalışma grubunu iki farklı devlet üniversitesinin eğitim fakültesinin son sınıfında öğrenim gören 830 öğretmen adayı oluşturmuştur. Açımlayıcı Faktör Analizi (AFA), 110 (53,6\%)’u kadın ve 95 (46,4 \%)'’i erkek olmak üzere toplam 205 öğretmen adayından elde edilen verilerle gerçekleştirilmiştir. Doğrulayıcı Faktör Analizi (DFA), 330 (52,8 \%) 'u kadın ve 295 (47,2 \%)'i erkek toplam 625 öğretmen adayı üzerinde gerçekleştirilmiştir. Dil eşdeğerliğini test etmek için İngilizceTürkçe; Türkçe-İngilizce geri çeviriler uygulanmıştır. Yapı geçerliği kapsamında AFA ve DFA'dan yararlanılmıştır. AFA sonucunda ölçeğin altı boyut ve 37 maddeden oluştuğu tespit edilmiştir. DFA sonucunda AFA'da elde edilen yapı doğrulanmıştır. Ölçme aracının güvenirliği için Cronbach Alpha güvenirlik katsayı ölçeğin tümünde 0.94 iken alt boyutlarında 0.70 ile 0.88 arasında değerler almıştır. Ölçme aracının geçerli ve güvenilir ölçüm yapabilen bir veri toplama aracı olduğu söylenebilir.

Anahtar

Kelimeler:

Pedagojik bilgi ve beceri, Öğretmen adayları, Geçerlik, Güvenirlik, Ölçek uyarlama

Cite This

Gökçek, T. \& Y1lmaz, A. (2019). The adaptation of the pedagogical knowledge and skills

Article:

survey into Turkish: Validity and reliability study, Turkish Journal of Education. 8(1), 52-70.

https://dx.doi.org/10.19128/turje.459678 


\section{INTRODUCTION}

Research on the development of teacher competence had of great interest in the last decade. Therefore, standardized instruments have been developed to measure the knowledge and skills of pre- and inservice teachers (Hill, 2010; Kersting, Givvin, Thompson, Santagata \& Stigler, 2012; König, Blömeke, Klein, Suhl, Busse, Kaiser, 2014). Pedagogical knowledge is about teaching and involves knowledge of how to teach content as a condition for teacher effectiveness (Hill, Rowan \& Ball, 2005). Pedagogical knowledge and skill are related to instructional techniques and strategies which enable learning to take place and encourage teachers to take on the roles of facilitators, coaches, models, evaluators, managers, and advocates. It helps teachers employ appropriate evaluation schemes. Effective pedagogy helps teachers display skills that could enable them to design curricula to build on learners' present knowledge and understanding and move those learners to more sophisticated and in-depth abilities, knowledge, concepts, and performances (Amosun \& Kolawole, 2015).

Many teacher education programs around the world aim to provide professional pedagogical knowledge and skills for future teachers (Tatto et al., 2008). According to König, Blömeke and Kaiser (2015), teacher competence is regarded as "a multidimensional construct, consisting of content knowledge (CK), pedagogical content knowledge (PCK) and general pedagogical knowledge (GPK) as well as of perception, interpretation and decision-making skills" (p.332). Also, Shulman (1986) proposed some categories which have been useful to conceptualize the kind of knowledge that teachers require. These categories are Subject Matter Knowledge (SMK), Pedagogical Knowledge (PK), and Pedagogical Content Knowledge (PCK). According to Ponte and Chapman (2006), the notion of PCK was introduced in the 1990s into the field. Since then, this one and the rest of the categories proposed by Shulman have influenced the research on mathematics teachers' knowledge (Sánchez, 2011; p.137). Many researchers have been inspired by Shulman's $(1986,1987)$ pedagogical content knowledge conceptions in mathematics education (Baumert, et al., 2010; Hill, Ball \& Schiling, 2008; König, et.al., 2014, 2015). Shulman (1986) used the term pedagogical content knowledge (PCK) and specific content knowledge in teaching to argue that content knowledge itself is not sufficient for teachers to be successful. Pedagogical content knowledge refers to the ability of the teacher to transform content into forms that are "pedagogically powerful and yet adaptive to the variations in ability and background presented by the students" (Shulman, 1987). An, Kulm and Wu (2004) also indicated that pedagogical content knowledge (PCK) addresses "how to teach mathematics content and how to understand students' thinking. This includes, taking into consideration both the cultural background of the students as well as their preferences for various teaching and learning styles" (p.146).

According to Shulman (1987) GPK involves "broad principles and strategies of classroom management and organization that appear to transcend subject matter" (p.8) as well as knowledge about learners, learning and assessment. König et al. (2015) argued that pre-service as well as in-service teachers are forced to reflect on tasks such as structuring lessons, motivating students prior, during and after the teaching process, and thus to activate their general pedagogical knowledge (GPK). Since the last decade, empirical tests have been developed to assess teachers' GPK. For instance, König, Blömeke, Paine, Schmidt and Hsieh (2011) revealed the multidimensional structure of GPK putting forward four factors; classroom structure, motivation and classroom management, students' heterogeneity and classroom assessment. Later König, Ligtvoet, Klemenz and Rothland (2017) worked with a sample of 573 preservice teachers in Austria to further validate the test in different countries, and positive intercorrelations were found between 


\section{Related Literature}

This section presents the research on the concepts of CK, PCK and GPK and explains how these concepts are employed. Thus, we summarize the literature and assess the pre-service teachers and inservice teachers' content knowledge, pedagogical content knowledge, general pedagogical knowledge and skills.

Koirala et.al (2008) developed a performance assessment task and rubric designed to assess secondary school mathematics pre-service teachers' pedagogical content knowledge and skills. The assessment task and rubric are well aligned with local, state, and national standards and provide insight into teacher candidates' pedagogical content knowledge and skills. Also, the project materials and outcomes have the potential to benefit other higher education institutions offering teacher education programs.

Karp (2010) analyses the experiences of secondary school mathematics teacher candidates during a teaching methods course offered prior to their micro teaching experience at school which involves reflexive analysis of the teaching. The study focuses on pedagogical challenges that arose in situations where prospective teachers lack the pedagogical content knowledge and skills during their teaching. The method used to process the data was the constant comparative method of analysis. As a result, author identified several sets of typical situations in which teacher candidates experienced difficulties.

Kleickman, et.al. (2015) examine whether the two-dimensional structure of teachers' content matter knowledge is cross-culturally invariant and whether the differences in teacher education are reflected in their content matter knowledge by comparing content knowledge (CK) and pedagogical content knowledge (PCK) of Taiwanese and German in-service mathematics teachers. They used paper and pencil tests to assess CK and PCK. Results confirmed that CK and PCK represent two distinct, but correlated dimensions. Also, Taiwanese teachers showed considerably higher CK and PCK scores than German teachers.

König et.al. (2011) discussed the TEDS-M (Teacher Education and Development Study in Mathematics) study which was taken by representative samples of future secondary school teachers in three countries, conceptualised a theoretical framework and developed a standardized test of GPK. The TEDS-M test measuring GPK of future secondary school teachers in the United States, Germany, and Taiwan. The test consisted of 77 test items which were equally distributed across the four content sub-dimensions and the three cognitive sub-dimensions. The data revealed that U.S. teacher candidates were outperformed by German or Taiwanese teachers. Also, US teachers showed a relative strength in one of the cognitive sub-dimensions, generating strategies to perform in the classroom, indicating that they had acquired procedural GPK during teacher education.

König et.al. (2014) examine how the declarative-conceptual general pedagogical knowledge assessed via a paper-pencil test can be understood as a premise for early career teachers' ability to notice and interpret classroom situations assessed via video-vignettes. As a conclusion, researchers found that GPK at the end of teacher education does not predict noticing or interpreting, which suggests that teachers' cognitions are reorganized during the transition into teaching.

König et.al. (2015) examined general pedagogical knowledge and skills of early career mathematics teachers, asking how they are associated with characteristics of teacher education, teaching experience, and working conditions. Data were collected from a sample of 278 early career secondary school mathematics teachers by using the follow-up study of TEDS-M Germany in 2012. Different competence profiles of pedagogical knowledge and skills are identified via latent-class analysis. Besides teaching experience, profiles are associated with generic teaching challenges such as motivating students, disruptive student behaviour perceived by the teachers.

Depaepe and König (2018) investigated the relationship between the GPK, self-efficacy (SE) and reported instructional practice based on a sample of 342 pre-service teachers. They found no significant 
difference between GPK and SE. On the other hand, SE significantly predicted all instructional practices, although GPK only predicted reported instructional practices related to student support.

When the research presented above is reviewed, it could be seen that pre-service teachers' pedagogical knowledge and skills are usually assessed by qualitative methods (such as interviews or observations). The research on teacher education particularly focuses on comparative TEDS-M data (Depaepe \& König, 2018; König, et. al., 2017). In this research, General Pedagogical Knowledge (GPK) was assessed with a paper-pencil test instrument which was developed and applied in the context of TEDSM. Adaptivity, structure, classroom management/motivation and assessment were identified in the test instrument as generic teaching dimensions.

Recently, there are some research looking at the pedagogical skills and knowledge of teacher candidates and early career teachers, and such research developed quantitative measurement tools. For instance, Chong, Choy and Wong (2008) examined the perceptions of pedagogical knowledge and skills in teaching held by pre-service teachers of the Postgraduate Diploma in Education programme in Singapore. The authors presented these findings at AARE conference in 2008. The longitudinal study collected data on why pre-service teachers wanted to become teachers, their attitudes, and perceived knowledge and skill levels towards teaching at the beginning and at the end of the teacher preparation programme. The survey instrument has 34 items with five factors; Facilitation; Assessment; Management; Preparation; and Care and concern. Findings showed that at the beginning, pre-service teachers already perceived that they had some pre-requisite pedagogical knowledge and skills. At the end of the programme, pre-service teachers displayed a significantly higher level of pedagogical knowledge and skills. Besides, pre-service teachers' perception of pedagogical knowledge was significantly higher for all five factors. As for perceptions of pedagogical skills, there were significant differences in all factors except for care and concern factor. This research was followed by another work of Choy, Chong, Wong and Wong (2011). They investigated changes in early career teachers' selfperceptions of their pedagogical knowledge and skills at the end of their initial teacher preparation and at the end of their first year of teaching. Factor analysis was used to extract factors from the 38 out of a total of 50 items in the survey. Using Principal Component Analysis, six factors with eigenvalues above 1.2 were extracted from 38 items and four items were dropped from the analysis. The six factors were: "Student Learning, Lesson Planning, Instructional Support, Accommodating Diversity, Classroom Management and Non-Teaching Duties". Surveys were administered to 322 final year students at the end of their initial teacher preparation programme and at the end of their first year of teaching to compare if there were any differences in their self-perceptions. The results showed significant increases in their perceptions of pedagogical knowledge and skills in three factors: Instructional Support, Accommodating Diversity and Classroom Management.

Later, Choy, Lim, Chong and Wong (2012) reported the cross-validation of the factor pattern of the Perceptions of Knowledge and Skills in Teaching (PKST) survey. The sample consisted of 323 primary and secondary pre-service teachers who were enrolled in the Postgraduate Diploma in Education (PGDE) initial teacher preparation program at the National Institute of Education in Singapore. The survey was distributed across six factors namely: student learning, lesson planning, instructional support, accommodating diversity, classroom management, and care and concern. A confirmatory factor analysis (CFA) was used to cross-validate the survey's factor pattern. The results showed that the model was an acceptable fit to the data. Following Wong, Chong, Choy \& Lim (2012) examined the levels of pedagogical knowledge and skills as perceived by 812 student teachers who were enrolled in the Post Graduate Diploma in Education program in Singapore. Their perceptions were assessed using the PKST survey which comprised six factors. Results showed that there were significant increases in participants' pedagogical knowledge and skills in all six factors from the start of their initial teacher preparation program until the end of their first year of teaching. However, during this phase, their perceived level of pedagogical knowledge in classroom management, and care and concern continued to increase significantly. Lastly, Choy, Wong, Lim and Chong (2013) investigated the early career teachers' perceptions of pedagogical knowledge and skills in teaching in Singapore. This study adopted part of the PKST survey (Choy et al., 2012) to measure the early career teachers' pedagogical knowledge and 
skills in teaching. The focus of this three-year study was to examine the early career teachers' perceptions of their own development in the following teaching related three factors: lesson planning, classroom management and instructional strategies. The results showed that early career teachers' pedagogical knowledge and skills increased significantly, but at different rates, in all three factors at the end of their third year of teaching.

As the literature suggests there are several research on CK, PCK, GPK and they mostly use paper-pencil tests. However, there is no quantitative survey or research tool that comprehensively looks at pedagogical knowledge and skill of teacher candidates or early careers teachers. Wong et al. (2012) developed this tool and used it with the teacher candidates in Singapur. In Turkey, recent research generally focused on content knowledge (Sivac1, 2017), PCK (pedagogical content knowledge) (Bukova-Güzel, Cantürk-Günhan, Kula, Özgür \& Elçi, 2013; Köse \& Selvi, 2016; Özel, Timur, Timur \& Bilen, 2013) and TPCK (technological pedagogical content knowledge) (Aydeniz \& Kirbulut, 2014; Balçın \& Ergün, 2016; Canbazoğlu-Bilici, Yamak, Kavak \& Guzey, 2013; Kabakçı-Yurdakul, et.al., 2012; Kaya \& Dağ, 2013; Kaya, Kaya \& Emre, 2013; Öztürk \& Horzum, 2011; Şahin, 2011; Timur \& Taşar, 2011) of teacher candidates and teachers and carried out survey development or adaptation studies. Yet, there is no research on pedagogical knowledge and skills. Therefore, this research aims to adapt the survey of Wong et al., (2012) to Turkish culture.

\section{METHODOLOGY}

This section includes the participants, the collection of data and the process of adapting the survey to Turkish.

\section{Participants}

This research aims to adapt Pedagogical Knowledge and Skills in Teaching (PKST) survey to Turkish and the participants of this research were final year education faculty students studying at two public universities in the Central Anatolia and Black Sea region of Turkey. The participants were studying in following departments: Science Education, Social Science Education, Elementary School Education, Physical Education, Mathematics Education. The research was carried out on two different sample groups. Explanatory Factor Analysis (EFA) was conducted with total 205 preservice teachers in which $110(53,6 \%)$ of female and $95(46,4 \%)$ of male. To test the structure resulting from EFA, Confirmatory Factor Analysis (CFA) was performed on different groups. CFA was carried out from the data taken from 625 preservice teachers in which $330(52,8 \%)$ of them are female, $295(47,2 \%)$ of them are male.

\section{Pedagogical Knowledge and Skills Survey}

This research aims to adapt the survey, which measures the pedagogical knowledge and skill levels of the Teacher Candidates and early career teachers, to Turkish culture. The validity and reliability of the survey was conducted by Wong, Chong, Choy and Lim (2012). The Survey has 38 items and 6 factors; Student Learning (7 items), Lesson planning (7 items), Instructional support (7 items), accommodating diversity (7 items), Classroom management (4 items), and Care and concern (6 items). The $\chi 2$ of the initial hypothesized model was $1,114.6$ with 603 degrees of freedom $(\mathrm{p}<.01)$. The ratio of $\chi^{2}$ to its degrees of freedom was 1.85, lower than the recommended indictor (3.0) of an acceptable fit between 
the hypothetical model and the sample data (Carmines \& McIver, 1981). Both TLI and CFI were 0.91, indicating an acceptable fit. The value of RMSEA was at 0.05 , indicating an acceptable fit, as it was lower than 0.07 . The results showed that the hypothesized model is acceptable. Finally, the Cronbach alpha reliability coefficient for the modified model was .95. Cronbach's alphas for the six latent constructs were: Student Learning (0.83), Lesson Planning (0.82), Instructional Support (0.77), Accommodating Diversity (0.71), Classroom Management (0.80), and Care and Concern of Students (0.81). The survey is a five-point Likert scale, the scores change between 1 (strongly disagree) and 5 (Strongly agree). All items of the survey are positive and no item is scored as reverse. The lowest and highest scores for the survey are 38 and 190, respectively.

The categories, descriptions, indicators, and some sample items of the Pedagogical Knowledge and Skill Survey are provided in Table1.

Table 1

Teacher candidates' characteristics related to pedagogical knowledge and skill levels

\begin{tabular}{|c|c|c|}
\hline Factors & Description & Indicators \\
\hline Student Learning & $\begin{array}{l}\text { Using different strategies to } \\
\text { capture students' interest and } \\
\text { stimulate their thinking }\end{array}$ & $\begin{array}{l}\text { Encouraging, } \\
\text { Attracting attention, } \\
\text { Critical and creative thinking, Motivation }\end{array}$ \\
\hline Lesson planning & $\begin{array}{l}\text { Writing lesson plans and } \\
\text { preparing appropriate } \\
\text { Resources }\end{array}$ & $\begin{array}{l}\text { Considering different skills, } \\
\text { Teaching according to the curriculum, } \\
\text { Determining the appropriate method for the content }\end{array}$ \\
\hline Instructional support & $\begin{array}{l}\text { Selecting appropriate resources } \\
\text { and assessment modes to support } \\
\text { instruction }\end{array}$ & $\begin{array}{l}\text { Developing Materials, } \\
\text { Using various assessment and evaluation tools, } \\
\text { Using Technology }\end{array}$ \\
\hline $\begin{array}{l}\text { Accommodating } \\
\text { diversity }\end{array}$ & $\begin{array}{l}\text { Catering to students' different } \\
\text { needs }\end{array}$ & $\begin{array}{l}\text { Considering students' needs and interests, } \\
\text { Responding to individual needs, } \\
\text { Monitoring student progress and performance }\end{array}$ \\
\hline Classroom management & $\begin{array}{l}\text { Managing student behaviors and } \\
\text { discipline }\end{array}$ & $\begin{array}{l}\text { Using techniques of appropriate class management, } \\
\text { Ensuring Discipline }\end{array}$ \\
\hline Care and concern & $\begin{array}{l}\text { Providing care and helping } \\
\text { students with problems }\end{array}$ & $\begin{array}{l}\text { Paying attention to students' needs, } \\
\text { Coping with stress }\end{array}$ \\
\hline
\end{tabular}

*While preparing Table 1, Wong, Chong, Choy and Lim (2012)'s study has been used.

\section{Ensuring Language Validity in Adaptation}

Firstly, we contacted Dorish Choy \& Angela F.L. Wong who are the corresponding authors of the survey to get permission to adapt the survey into Turkish. The authors emailed the latest version of the survey. Back-translation was done during the adaptation process, as suggested by Brislin (1986). Three different academics in the field of Mathematics Education, Pre-school education and Educational Research separately translated the survey items. These three translations were compared with each other to understand the consistency and to discuss the items and then Turkish translation form was prepared. A linguist was asked to have a look at the Turkish translation form and the original survey. The necessary corrections have been made and the form has been given to a language expert for the translation of the articles in Turkish form into English. The purpose of this translation is to provide evidence of language validity between the original scale items and the items translated into English. After the necessary amendments, a translator translated the survey items in the form to ensure language validity in the back translation. Thus, the scale form which was adapted to Turkish was finalized.

\section{Data Collection and Analysis}

Researchers informed the teacher candidates and ensured that they completed the form accurately. The data was collected during the Spring term of 2016-2017 academic year in two public universities in 
Trabzon and Kırıkkale with students of Elementary School teaching, Mathematics teaching, Physcial education teaching and Social sciences education. In total, 642 teacher candidates participated in the research.

Seventeen forms had missing information and were filled incorrectly. Therefore, they were left out of the analysis. 625 forms were analyzed, $330(52,8 \%)$ of them were women, and $295(47,2 \%)$ of them were men. SPSS 22 and Lisrel 8.8 were used in data analysis. In the study, firstly, the factor analysis was carried out. Afterwards, Confirmatory Factor analysis was used to identify whether the survey was appropriately adapted to Turkish culture. Then, item analysis, item total test correlation and 27\% subgroup analysis were conducted. Then, Cronbach Alpha Coefficient was calculated.

\section{FINDINGS}

This section presents the findings of validity and reliability analyses.

\section{Validity Analysis}

According to Seçer (2015), the theoretical structure of the measurement tool shows the level of the relationship between each item. To adapt the original survey to the Turkish culture, firstly EFA was conducted. After, CFA is used to test the construct validity (Kline, 2005). CFA is commonly used in adaptation studies to test whether the survey is appropriately fit to a different culture. In this research, CFA was used to test whether the structure with six factors and 38 items showed the same structure on different groups with similar characteristics.

\section{Exploratory Factor Analysis}

In order to provide evidence for the construct validity of the survey, statistical technique Exploratory Factor Analysis (EFA) was used to gather variables (items) that measure the same structure together with a smaller number of variables. Kaiser-Mayer-Olkin (KMO) coefficient and Bartlett test results were examined for the suitability of the study group for factor analysis. KMO sample suitability value was found as 0.92 and Barlet-Sphericity test chi square value was found as 4214,773 ( $<<0.01$ ). These values indicate that the data from the study group is perfectly suited to factor analysis.

"Principal Component Analysis" was used in the study. In the Principal Component Analysis, contribution of each factor to the total variance and implicit variables with an eigenvalue is greater than 1. So, the Kaiser-Guttman principle was considered when deciding the number of factors (Kline, 2005). In the present study, varimax rotation technique was used.

Tavşanc1l (2014) recommends that the item factor load values of the items should be greater than 0.30 . In the present study, the item factor load value was determined as 0.35 . In the removal of items that do not measure the same structure in EFA, attention was paid to the fact that the item loadings were not higher than 0.35. In addition, common factor variances showing the relationship power of factors with the factor should be higher than 0.40 . Common variance values of the items in the survey were between 0.41 and 0.71 . Factor load factor values that explain the factors and factors obtained as a result of exploratory factor analysis are shown in Table 2. 
Table 2.

PKST items and item factor load values

\begin{tabular}{|c|c|c|c|c|c|c|c|c|}
\hline & Items & $\begin{array}{c}\text { Common } \\
\text { Variances }\end{array}$ & 1. D & 2.D & 3.D & 4. D & 5. D & 6. D* \\
\hline \multirow{8}{*}{ 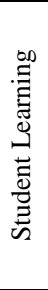 } & 1. Developing students' interest in learning. & ,702 &, 782 & & & & & \\
\hline & 2. Arousing students' interest in my subject area. & ,709 &, 758 & & & & & \\
\hline & 3. Infusing critical thinking appropriately in the lessons. & ,622 & ,666 & & & & & \\
\hline & 4. Infusing creative thinking appropriately in the lessons. &, 584 & ,650 & & & & & \\
\hline & 5. Facilitating and stimulating thinking among students. &, 574 & ,661 & & & & & \\
\hline & 6. Using student-centred teaching and learning activities. &, 514 &, 552 & & & & & \\
\hline & 7. Motivating students to work hard. & ,484 & ,591 & & & & & \\
\hline & Explained Variances & $\% 17,46$ & & & & & & \\
\hline \multirow{8}{*}{ 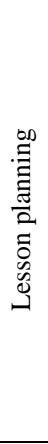 } & $\begin{array}{l}\text { 8. Choosing appropriate teaching strategies for teaching } \\
\text { particular topics. }\end{array}$ & ,666 & & ,754 & & & & \\
\hline & $\begin{array}{l}\text { 9. Choosing teaching strategies that match students' } \\
\text { different ability levels. }\end{array}$ &, 527 & & ,603 & & & & \\
\hline & $\begin{array}{l}\text { 10. Asking students the right questions to facilitate their } \\
\text { learning. }\end{array}$ & 484 & &, 532 & & & & \\
\hline & 11. Translating the syllabus into lessons for instruction. & ,425 & & ,472 & & & & \\
\hline & $\begin{array}{l}\text { 12. Planning lessons that take into consideration the } \\
\text { different abilities of students. }\end{array}$ & 649 & & 669 & & & & \\
\hline & 13. Determining appropriate teaching methods. & 652 & &, 536 & & & & \\
\hline & 14. Planning student centred lessons. & ,613 & &, 599 & & & & \\
\hline & Explained Variances & $\% 16,047$ & & & & & & \\
\hline \multirow{7}{*}{ 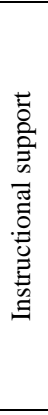 } & 15. Producing my own teaching materials & ,712 & & & ,769 & & & \\
\hline & $\begin{array}{l}\text { 16. Acquiring appropriate teaching materials for my } \\
\text { lessons }\end{array}$ & ,700 & & &, 587 & & & \\
\hline & $\begin{array}{l}\text { 17.Incorporating information and communication } \\
\text { technology (ICT) effectively in the classroom. }\end{array}$ & ,640 & & & ,605 & & & \\
\hline & $\begin{array}{l}\text { 18. Designing assessment tools (e.g., written tests, oral } \\
\text { tests, science practical, etc.) }\end{array}$ & 682 & & & ,686 & & & \\
\hline & 20. Using appropriate forms of assessment. &, 587 & & & ,484 & & & \\
\hline & $\begin{array}{l}\text { 21. Acquiring relevant subject matter content for } \\
\text { instruction. }\end{array}$ & ,435 & & & ,566 & & & \\
\hline & Explained Variances & $\% 7.297$ & & & & & & \\
\hline \multirow{8}{*}{ 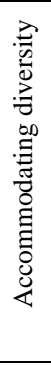 } & $\begin{array}{l}\text { 22.Using evaluative feedback to assist students in their } \\
\text { progress. }\end{array}$ &, 537 & & & & ,479 & & \\
\hline & 23. Teaching according to students' pace. &, 530 & & & &, 581 & & \\
\hline & 24. Diagnosing students' learning difficulties. & ,593 & & & & ,587 & & \\
\hline & 25.Responding sensitively to different student needs. & ,638 & & & &, 597 & & \\
\hline & 26. Managing student learning-groups effectively. &, 531 & & & & ,456 & & \\
\hline & 27. Managing individual students' learning effectively. &, 580 & & & & 690 & & \\
\hline & $\begin{array}{l}\text { 28.Monitoring students' learning and performance durıng } \\
\text { lessons. }\end{array}$ &, 514 & & & & ,391 & & \\
\hline & Explained Variances & $\% 6,377$ & & & & & & \\
\hline \multirow{5}{*}{ 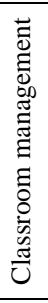 } & $\begin{array}{l}\text { 29. Applying appropriate classroom management } \\
\text { techniques. }\end{array}$ & ,410 & & & & & ,453 & \\
\hline & $\begin{array}{l}\text { 30.Managing students with behavioral and learning } \\
\text { problems. }\end{array}$ & 601 & & & & &, 522 & \\
\hline & $\begin{array}{l}\text { 31.Using appropriate strategies to monitor student } \\
\text { behavior. }\end{array}$ & ,509 & & & & &, 513 & \\
\hline & 32. Managing student discipline. & ,635 & & & & & ,711 & \\
\hline & Explained Variances & $\% 6,079$ & & & & & & \\
\hline \multirow{8}{*}{ 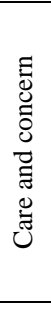 } & 33. Managing co-curricular activities. & ,598 & & & & & & ,658 \\
\hline & 34. Managing time effectively. &, 592 & & & & & &, 506 \\
\hline & 35. Having coping skills & ,702 & & & & & &, 711 \\
\hline & 36. Managing stress. &, 575 & & & & & &, 707 \\
\hline & $\begin{array}{l}\text { 37. Showing concern for the holistic development of } \\
\text { students. }\end{array}$ & 671 & & & & & & ,654 \\
\hline & 38. Showing care and concern for students. & ,676 & & & & & &, 748 \\
\hline & Explained Variances & $\% 5,539$ & & & & & & \\
\hline & Explained Total Variances & $\% 59,063$ & & & & & & \\
\hline
\end{tabular}


Table 2 presents the items and their factor load values. The original survey has six factors. When it was adapted to Turkish culture, the original survey did not lose any of its factors. However, only item 19 in 'Instructional support' was removed as it was not sufficiently explained. When the item factor load values are taken into consideration, it is seen that the error variance of the item factor load value of item 19 in the "Instructional support" is 0.09 . According to many researchers, the factor load factor of the factors should be greater than 0.30 (De Vellis, 2014; Seçer, 2013; Tavşanc1l, 2014). Ferguson and Takane (1989) stated that the lower cut-off point should be taken as 0.40 for the item factor load value to ensure factor pattern. When this criterion was taken into consideration, the item 19, 'I assess students' performance based on the exam scores' was removed as it's factor load was 0.09. Thus, the EFA was conducted without subtracting item 19 from the survey and the item factor loadings of the item in "Instructional support" varied between 0.09 and 0.71 . It was found that the item factor load value was between 0.43 and 0.71 after the EFA upon subtracting the item whose factor load value was below 0.30 .

Lastly, the adapted survey has 6 factors and 37 items. These six factors explain 59,063\% of the total variance of the feature. Considering that the variance rates varying from $40 \%$ to $60 \%$ are considered adequate in the analysis in social sciences (Tavşanc11,2014), it can be argued that the amount of variance explained is sufficient.

\section{Confirmatory Factor Analysis}

The factor structure in the original survey needs to be confirmed to adapt Pedagogical Knowledge and Skills Survey to Turkish, and therefore CFA was employed. To demonstrate the adequacy of the model tested in CFA, several adaptation indices were used (Büyüköztürk, Kılıç-Çakmak, Akgün, Karadeniz \& Demirel, 2012). * Table 3 presents acceptable and well-considered value ranges for the fit indices in accordance with the relevant literature and the values obtained in the study.

Table 3.

Results of confirmatory factor analysis

\begin{tabular}{|c|c|c|c|}
\hline $\begin{array}{c}\text { Compliance Index Model } \\
\mathrm{X}^{2} / \mathrm{sd} \\
\end{array}$ & $\begin{array}{c}* \text { Optimum range } \\
0<\mathrm{X}^{2} / \mathrm{sd}<2\end{array}$ & $\begin{array}{c}\text { Acceptable Range } \\
2<\mathrm{X}^{2} / \mathrm{sd}<3\end{array}$ & $\begin{array}{c}* * \mathrm{PKST} \\
3.00 \\
\end{array}$ \\
\hline RMSEA & $0.00<$ RMSEA $<0.05$ & $0.05<$ RMSEA $<0.10$ & 0.05 \\
\hline PGFI & $0.95<$ PGFI $<1.00$ & $0.50<\mathrm{PGFI}<0.95$ & 0.75 \\
\hline PNFI & $0.95<\mathrm{PNFI}<1.00$ & $0.50<\mathrm{PNFI}<0.95$ & 0.89 \\
\hline GFI & $0.90<\mathrm{GFI}<1.00$ & $0.85<\mathrm{GFI}<0.90$ & 0.87 \\
\hline AGFI & $0.90<\mathrm{AGFI}<1.00$ & $0.85<\mathrm{AGFI}<0.90$ & 0.85 \\
\hline IFI & $0.95<\mathrm{IFI}<1.00$ & $0.90<\mathrm{IFI}<0.95$ & 0.98 \\
\hline NFI & $0.95<\mathrm{NFI}<1.00$ & $0.90<\mathrm{NFI}<0.95$ & 0.97 \\
\hline CFI & $0.95<\mathrm{CFI}<1.00$ & $0.90<\mathrm{CFI}<0.95$ & 0.98 \\
\hline
\end{tabular}

*Sümer, 2000; Schermelleh-Engel \& Moosbrugger, 2003; Kline, 2005; Tabachnick \& Fidell, 2007; Thompson, 2004; Jöreskog \& Sörbom, 1993; Schumacher \& Lomax, 1996; Hooper, Coughlan \& Mullen, 2008; Brown, 2006. ** PKSS: Pedagogical Knowledge and Skills Survey

Fit indices in Table 3 are as follows; $\mathrm{x} 2 / \mathrm{sd}=3.00$, RMSEA $=0.05$, PGFI $=0.75, \mathrm{GFI}=0.87, \mathrm{AGFI}=0.85$, $\mathrm{PNFI}=0.89, \mathrm{IFI}=0.98, \mathrm{NFI}=0.97$ and $\mathrm{CFI}=0.98$. Taking these fit indices into consideration, it can be argued that the data confirms 6 -dimensional theoretical construction. The study reveals that $\mathrm{x} 2 / \mathrm{sd}=3.00$. As $\chi^{2}$ is sensitive to the size of the sample, the $\chi^{2}$ value increases as the sample increases (Çokluk, Şekercioğlu \& Büyüköztürk, 2012). The t values of the items in the six-factor structure are given in Table 4. 
Table 4.

$T$ values obtained from confirmatory factor analysis

\begin{tabular}{llllllll}
\hline Item & $\mathrm{t}$ & Item & $\mathrm{T}$ & Item & $\mathrm{T}$ & Item & $\mathrm{T}$ \\
\hline 1 & $21.31^{* *}$ & 11 & $15.27^{* *}$ & 22 & $19.03^{* *}$ & 32 & $12.40^{* *}$ \\
2 & $21.40^{* *}$ & 12 & $16.46^{* *}$ & 23 & $19.60^{* *}$ & 33 & $15.04^{* *}$ \\
3 & $22.94^{* *}$ & 13 & $21.37^{* *}$ & 24 & $18.00^{* *}$ & 34 & $17.82^{* *}$ \\
4 & $22.60^{* *}$ & 14 & $16.46^{* *}$ & 25 & $19.07^{* *}$ & 35 & $19.20^{* *}$ \\
5 & $20.51^{* *}$ & 15 & $16.59^{* *}$ & 26 & $18.77^{* *}$ & 36 & $15.70^{* *}$ \\
6 & $17.96^{* *}$ & 16 & $19.29^{* *}$ & 27 & $19.16^{* *}$ & 37 & $21.80^{* *}$ \\
7 & $15.19^{* *}$ & 17 & $17.19^{* *}$ & 28 & $18.66^{* *}$ & 38 & $19.16^{* *}$ \\
8 & $20.15^{* *}$ & 18 & $13.96^{* *}$ & 29 & $19.05^{* *}$ & & \\
9 & $19.07^{* *}$ & 20 & $13.21^{* *}$ & 30 & $18.83^{* *}$ & & \\
10 & $17.36^{* *}$ & 21 & $15.64^{* *}$ & 31 & $18.57^{* *}$ & & \\
\hline
\end{tabular}

Table 4 shows the t-test values for the model with six factors and 38 items. These values range between 15.19 and 22.94 in the "Student Learning"; 15.27 and 21.37 in the "Lesson planning"; 13.21 and 19.29 in the "Instructional support"; 18.66 and 19.60 in the 'Accommodating diversity", 12.40 and 19.05 in the "Classroom management" and 15.04 and 21.80 in "Care and concern". The literature suggests that the value of $t$ should be higher than 1.96 and significant at the level of .05 and higher than 2.58 and significant at the level of .001 (Jöreskog \& Sörbom, 1993; Kline, 2011). According to this, all $t$ values in CFA, show significant difference at the level of .001except for item 19 (Byrne, 2010). Also, the values of $t$ in this factor were between 13.21 and 22.94. The "Pedagogical Knowledge and Skill Survey" composed of 6 factors and 37 items was confirmed as a result of CFA.

\section{Item Analyses}

Item-total test correlation was used to determine if each item could measure what they should measure and to what extent each item was sufficient in distinguishing between the characteristics of measurement (Büyüköztürk et al., 2012). The item total test correlation describes the relationship between scores from test items and the total score of the test. If the correlation of an item with the total score is low, it indicates that the item measures a different quality than the other items in the scale (Karasar, 2014). Item-total test correlations have good distinguishing characteristics if items have a score of 0.30 or higher (Büyüköztürk, 2014; Erkuş, 2014). Table 5 shows the values of item analyses.

Table 5.

Results of item analysis of pedagogical knowledge and skill survey

\begin{tabular}{|c|c|c|c|c|c|c|c|c|}
\hline \multirow{2}{*}{ Dimensions } & \multirow{2}{*}{ No } & \multicolumn{2}{|c|}{$\% 27$ Top group $(n=168)$} & \multicolumn{2}{|c|}{$\% 27$ bottom group $(n=168)$} & \multirow[b]{2}{*}{$\mathrm{t}$} & \multirow[b]{2}{*}{$\mathrm{p}$} & \multirow{2}{*}{$\begin{array}{c}\text { Item Total Test } \\
\text { Correlation }\end{array}$} \\
\hline & & $\mathrm{x}$ & SS & $\mathrm{X}$ & SS & & & \\
\hline \multirow{7}{*}{ Student learning } & 1 & 4,71 & 0,47 & 3,65 & 0,81 & 14,47 & 0,00 & 605 \\
\hline & 2 & 4,71 & 0,47 & 3,68 & 0,84 & 13,78 & 0,00 & 629 \\
\hline & 3 & 4,64 & 0,49 & 3,56 & 0,85 & 14,27 & 0,00 &, 654 \\
\hline & 4 & 4,73 & 0,44 & 3,66 & 0,77 & 15,40 & 0,00 &, 627 \\
\hline & 5 & 4,71 & 0,45 & 3,75 & 0,73 & 14,51 & 0,00 &, 622 \\
\hline & 6 & 4,70 & 0,58 & 3,66 & 0,87 & 12,92 & 0,00 & 627 \\
\hline & 7 & 4,47 & 0,72 & 3,38 & 0,87 & 12,43 & 0,00 &, 536 \\
\hline \multirow{7}{*}{ Lesson planning } & 8 & 4,68 & 0,49 & 3,70 & 0,72 & 14,39 & 0,00 & 655 \\
\hline & 9 & 4,60 & 0,55 & 3,31 & 0,91 & 15,60 & 0,00 & ,601 \\
\hline & 10 & 4,69 & 0,51 & 3,74 & 0,81 & 12,69 & 0,00 &, 580 \\
\hline & 11 & 4,50 & 0,62 & 3,48 & 0,86 & 12,30 & 0,00 &, 546 \\
\hline & 12 & 4,53 & 0,59 & 3,25 & 0,95 & 14,67 & 0,00 &, 571 \\
\hline & 13 & 4,70 & 0,47 & 3,61 & 0,75 & 15,75 & 0,00 & ,671 \\
\hline & 14 & 4,66 & 0,54 & 3,62 & 0,82 & 13,67 & 0,00 &, 585 \\
\hline \multirow{4}{*}{ Instructional support } & 15 & 4,50 & 0,63 & 3,37 & 0,99 & 12,40 & 0,00 &, 545 \\
\hline & 16 & 4,64 & 0,58 & 3,50 & 0,84 & 14,41 & 0,00 & ,596 \\
\hline & 17 & 4,64 & 0,51 & 3,36 & 0,88 & 16,18 & 0,00 & ,579 \\
\hline & 18 & 4,40 & 0,91 & 3,42 & 0,95 & 9,57 & 0,00 & ,456 \\
\hline
\end{tabular}




\begin{tabular}{|c|c|c|c|c|c|c|c|c|}
\hline & 20 & 4,33 & 0,78 & 3,29 & 0,92 & 11,18 & 0,00 & ,461 \\
\hline & 21 & 4,64 & 0,53 & 3,66 & 0,85 & 12,69 & 0,00 &, 584 \\
\hline \multirow{7}{*}{ Accommodating diversity } & 22 & 4,70 & 0,45 & 3,67 & 0,77 & 14,89 & 0,00 & ,665 \\
\hline & 23 & 4,59 & 0,56 & 3,46 & 0,82 & 14,69 & 0,00 & 628 \\
\hline & 24 & 4,50 & 0,62 & 3,39 & 0,86 & 13,37 & 0,00 & ,586 \\
\hline & 25 & 4,53 & 0,54 & 3,53 & 0,72 & 14,27 & 0,00 & ,612 \\
\hline & 26 & 4,59 & 0,53 & 3,51 & 0,77 & 14,89 & 0,00 & ,612 \\
\hline & 27 & 4,53 & 0,53 & 3,50 & 0,75 & 14,38 & 0,00 & ,608 \\
\hline & 28 & 4,63 & 0,50 & 3,62 & 0,77 & 14,21 & 0,00 & ,660 \\
\hline \multirow{4}{*}{ Classroom management } & 29 & 4,61 & 0,51 & 3,58 & 0,87 & 13,13 & 0,00 & ,637 \\
\hline & 30 & 4,58 & 0,58 & 3,55 & 0,83 & 14,06 & 0,00 & ,588 \\
\hline & 31 & 4,49 & 0,65 & 3,52 & 0,83 & 11,85 & 0,00 & ,594 \\
\hline & 32 & 4,34 & 0,68 & 3,28 & 0,94 & 11,74 & 0,00 &, 458 \\
\hline \multirow{6}{*}{ Care and concern } & 33 & 4,54 & 0,68 & 3,47 & 0,90 & 12,15 & 0,00 & 569 \\
\hline & 34 & 4,59 & 0,64 & 3,58 & 0,83 & 12,31 & 0,00 & ,579 \\
\hline & 35 & 4,53 & 0,60 & 3,47 & 0,81 & 13,46 & 0,00 & ,559 \\
\hline & 36 & 4,35 & 0,78 & 3,34 & 0,90 & 10,87 & 0,00 & ,453 \\
\hline & 37 & 4,77 & 0,44 & 3,57 & 0,84 & 16,23 & 0,00 & ,671 \\
\hline & 38 & 4,78 & 0,45 & 3,78 & 0,93 & 12,49 & 0,00 & ,622 \\
\hline
\end{tabular}

When the findings in Table 5 are considered, the item-total test correlation is between 0.45 and 0.67 . This indicates that each item on the survey is compatible with the pedagogical knowledge and skills. Differences between top and bottom group mean scores of $27 \%$ were examined to determine whether the items with the desired characteristics where distinguished from those that did not have (Kıliç Çakmak, Çebi \& Kan, 2014). Therefore, an independent t-test was used to determine the difference between the groups. The results show that $t$ values changed between 9.57 (sd: 337, p <0.01) and 16.23 (sd: 337, $\mathrm{p}<0.01$ ). According to Erkuş (2014), the significance of the $t$ values for the differences between the top and bottom groups provides evidence for the distinctiveness of the item.

\section{Findings Related to Reliability}

Reliability is the ability of a measurement tool to produce consistent results (sensitive to random faults) (Tezbaşaran, 1996). In this study, the Cronbach Alpha internal consistency coefficient for the survey and its factors was calculated. The results are presented in Table 6.

Table 6.

Reliability results of PKST survey

\begin{tabular}{lc}
\hline Dimensions & Cronbach Alpha \\
\hline Student Learning & 0.88 \\
Lesson planning & 0.83 \\
Instructional support & 0.70 \\
Accommodating diversity & 0.86 \\
Classroom management & 0.73 \\
Care and concern & 0.83 \\
Pedagogical Knowledge and Skill Survey & 0.94 \\
\hline
\end{tabular}

Table 6 presents the reliability coefficient for the Pedagogical Knowledge and Skill Survey and its factors. Cronbach Alfa reliability coefficient was used in reliability analysis. This coefficient was 0.88 for Student Learning;0.83 for "Lesson planning"; 0.70 for "Instructional support"; 0.86 for "Accommodating diversity"; 0.73 for "Classroom management"; and 0.83 for "Care and concern." Reliability analysis value should be at least 0.70 (Anderson, 1988; Kline, 1994; Nunnaly, 1978; Peers, 1996). Reliability analysis results indicate that the factors are highly reliable. 


\section{The relationship between the Survey and its dimensions}

Pearson Correlation Analysis is used to identify the level of relationship between the survey and its factors. The results are presented in Table 7.

Table 7.

Pearson correlation analysis results

\begin{tabular}{lccc}
\multicolumn{1}{c}{ Dimensions } & \multicolumn{3}{c}{ Pedagogical Knowledge and Skill Survey (PKSS) } \\
& $\mathrm{N}$ & $\mathrm{r}$ & $\mathrm{p}$ \\
\hline Student Learning & 625 & 0.82 & $0.00^{* *}$ \\
Lesson planning & 625 & 0.87 & $0.00^{* *}$ \\
Instructional support & 625 & 0.79 & $0.00^{* *}$ \\
Accommodating diversity & 625 & 0.87 & $0.00^{* *}$ \\
Classroom management & 625 & 0.79 & $0.00^{* *}$ \\
Care and concern & 625 & 0.81 & $0.00^{* *}$ \\
\hline
\end{tabular}

$\mathrm{p}<0.01$

When Table 7 is examined, it is seen that there is a high level of positive correlation between the survey and the factor $(\mathrm{P}<0.01)$. It can be said that the factors are highly correlated with the overall survey, indicating that a total score can be taken from the survey.

\section{DISCUSSION and CONCLUSION}

This research aims to provide a tool to measure the pedagogical knowledge and skill levels of teacher candidates and early career teachers and contribute to the Turkish literature. Different measurement tools have been developed to measure pedagogical knowledge and skills (Chong, et.al., 2008; Choy, et.al., 2011; Choy, et.al., 2012). The first of these tools was developed by Chong, et.al. (2008) and it included factors of facilitation, assessment, management, preparation, care and concern. Choy, et.al. (2011) built upon their previous work and conducted a longitudinal research to investigate the perception of pedagogical knowledge and skills of early career teachers. They used a measurement tool that has 6 factors (Student Learning, Lesson Planning, Instructional Support, Accommodating Diversity Classroom Management and Non-Teaching Duties) and 38 items. Later on, Choy, et.al. (2012) developed a measurement tool with a structure consisting of 37 items and six factors (student learning, lesson planning, instructional support, accommodating diversity, classroom management, and care and concern). When the studies on pedagogical knowledge and skill were examined, it was seen that the number of factors changed between four and six and items ranged between 34 and 38. Finally, the Pedagogical Knowledge and Skill Survey, consisting of 38 factors and six factors, was used by Wong et.al (2012) to measure pedagogical knowledge and skill. This research adapts this instrument to Turkish culture.

While adapting the survey to Turkish, the necessary permission was obtained via e-mail from the leading author. First, measures to ensure language reliability were taken. The standard back- translation technique proposed by Brislin (1986) was used to translate the survey. Lecturers with good English language skills translated the survey. Then, the consistency of the translation was examined by comparing the translations with each other. Later, a translation form was prepared, and Turkish translation form and original survey items were presented to language experts. The necessary corrections were made and the form was given to a language expert so that the materials in Turkish form can be translated into English again. The aim in this translation was to provide linguistic validity between the original survey items and its back translations. 
CFA was used to determine whether six factors (student learning, lesson planning, instructional support, accommodating diversity, classroom management, care and concern) and the measurement model consisting of 38 items were verified by the data. Prior to confirmatory factor analysis, item analyses were conducted, and item-total test correlation was calculated. The high item-total correlation suggests that the items exemplify similar behaviors (Büyüköztürk et al., 2012). In this study, the item-total test correlation values changed between 0.45 and 0.67 . This indicates that each item on the survey is completely coherent with the survey. In the study, a t-test was conducted to determine the significance of the difference between the item scores of the top $27 \%$ and bottom $27 \%$ groups. The values were found to be between 10.01 (sd: 337, p <0.01) and 16.50 (sd: 337, p <0.01). The significance of t values is an evidence of the distinctiveness of the material (Erkuş, 2014).

CFA was conducted after the item analyses. The CFA analysis showed that the item factor load value of item 19 was lower than 0.30 and the error variance was high. Therefore, this item was removed, and the analyses were repeated. The fit index of the survey are as follows; $\mathrm{x} 2 / \mathrm{sd}=3.00, \mathrm{RMSEA}=0.05$, $\mathrm{PGFI}=0.75, \mathrm{GFI}=0.87, \mathrm{AGFI}=0.85, \mathrm{PNFI}=0.89, \mathrm{IFI}=0.98, \mathrm{NFI}=0.97$ and $\mathrm{CFI}=0.98$. CFA fit indices verify psychological construct of six factors. $\mathrm{T}$ values of the subscale ranged between 15.19 and 22.94 for student learning, 15.27 and 21.37 for lesson planning, 13.21 and 19.29 for instructional support, 18.66 and 19.60 for accommodating diversity, 12.40 and 19.05 for classroom management, 15.04 and 21.80 for care and concern. CFA factor loads ranged between 0.74 and 0.70 for student learning, 0.58 and 0.75 for lesson planning, 0.49 and 0.70 for instructional support, 0.67 and 0.71 for accommodating diversity, 0.50 and 0.72 for classroom management, and 0.57 and 0.77 for care and concern. As a matter of fact, it can be said that the factor loads reflect the large effect sizes. Findings of CFA show that the survey is valid.

The reliability coefficient of the survey is 0.94 . This coefficient is 0.88 for student learning, 0.83 for lesson planning, 0.70 for instructional support, 0.86 for accommodating diversity, 0.73 for classroom management and 0.83 for care and concern. This shows that the survey is reliable. The survey is a 5point Likert scale. The lowest score one can get is 37 and the highest is 185 . The results of analyses show that the survey is valid and reliable, and it has been successfully adapted to Turkish culture.

\section{REFERENCES}

Alkan, S., Korkmaz, E., Korkmaz, C., \& Gelici, Ö. (2017). Determination of the relationship between pedagogical field knowledge in teaching mathematics of classroom teacher candidates. Mustafa Kemal University Journal of the Faculty of Education, 1 (1), 15-25.

Amosun, M.D., \& Kolawole, O. A. (2015). Pedagogical knowledge and skill competencies of pre-school teachers in Ibadan Metropolis, Oyo State, Nigeria. Journal of the International Society for Teacher Education, 19 (2), 6-14.

An, S., Kulm, G., \& Wu, Z. (2004). The pedagogical content knowledge of middle school, mathematics teachers in China and the U.S. Journal of Mathematics Teacher Education, 7(2), 145-172.

Anderson, L.W. (1988). Attitudes and their measurement. In J. P. Keeves (Ed.), Educational research, methodology and measurement: An international handbook (pp. 885-895). New York: Pergamon Press.

Aydeniz, M., \& Kirbulut, Z.D. (2014). Exploring challenges of assessing pre-service science teachers' pedagogical content knowledge (PCK). Asia-Pacific Journal of Teacher Education, 42(2), 147-166. doi.org/10.1080/1359866X.2014.890696

Baumert, J., Kunter, M., Blum, W., Brunner, M., Voss, T. Jordan A et al. (2010). Teachers' mathematical knowledge, cognitive activation in the classroom, and student progress. American Educational Research Journal, 47(1), 133-180. doi: 10.3102/0002831209345157.

Balçın, M.D., \& Ergün, A. (2016). Technological pedagogical content knowledge (TPCK) self-efficacy scale for pre-service science teachers on material development: Development, reliability and validity study. Turkish Journal of Education, 5 (3), 130-143. 
Brislin, R.W. (1986). The wording and translation of research instrument. In W. J. Lonner \& J. W. Berry (Eds.), Field methods in cross-cultural research (pp. 137-164). Beverly Hills, CA: Sage.

Bukova-Güzel, E., Cantürk-Günhan, B., Kula, S., Özgür, Z., \& Elçi, A.N. (2013). Scale development for preservice mathematics teachers' perceptions related to their pedagogical content knowledge. South African Journal of Education, 33 (2), 1-21.

Büyüköztürk, Ş., Kılıç-Çakmak, E., Akgün, Ö.E. Karadeniz, Ş., \& Demirel, F. (2012). Bilimsel araştırma yöntemleri (Improved 11. Print). Ankara: Pegem Akademi Publishing.

Büyüköztürk, Ş. (2014). Sosyal bilimler için veri analizi el kitabı: Istatistik, araştırma deseni spss uygulamaları ve yorum (Expanded 20. Print). Ankara: Pegem Akademi Publishing.

Byrne, B.M. (2013). Structural equation modeling with Mplus: Basic concepts, applications, and programming. Routledge.

Canbazoğlu-Bilici, S., Yamak, H., Kavak, N., \& Guzey, S.S. (2013). Technological pedagogical content knowledge self-efficacy scale (TPACK-SeS) for preservice science teachers: Construction, validation and reliability. Eurasian Journal of Educational Research, 52, 37-60.

Chong, S., Choy, D., \& Wong, F.L. (2008, March). Pedagogical knowledge and skills of pre-service primary school teachers. Paper presented at the AARE Conference, Brisbane, Australia. Retrieved 15 October, 2015, from https://www.aare.edu.au/data/publications/2008/cho08307.pdf

Choy, Doris, Sylvia Chong, Angela F. L. Wong, \& Isabella Y.-F. Wong. (2011). Beginning Teachers’ Perceptions of Their Levels of Pedagogical Knowledge and Skills: Did They Change since Their Graduation from Initial Teacher Preparation? Asia Pacific Education Review 12 (1), 79-87.

Choy, D., Lim, K.M., Chong, S., \& Wong, Angela F.L. (2012). A confirmatory factor analytic approach on perceptions of knowledge and Skills in teaching (PKST). Psychological Reports, 110 (2), 589-597. doi.org/10.2466/03.11.PR0.110.2.589-597.

Choy, D., Wong Angela, F.L., Lim, K.M., \& Chong, S. (2013). Beginning teachers' perceptions of their pedagogical knowledge and skills in teaching: A three-year study. Australian Journal of Teacher Education, 38(5), 68-79. doi.org/10.14221/ajte.2013v38n5.6.

Çokluk, Ö., Şekercioğlu, G., \& Büyüköztürk, Ş. (2012). Sosyal bilimler için çok değişkenli istatistik spss ve lisrel uygulamalart (2. Print). Ankara: Pegem Akademi Publishing.

De Vellis, R.F. (2014). Ölçek geliştirme: Kuram ve uygulamalar (Ed. Tarık Totan). Ankara: Nobel Publishing.

Erkuş, A. (2014). Psikolojide ölçme ve ölçek geliştirme-I: Temel kavramlar ve işlemler (2. Ed). Ankara: Pegem Publishing.

Ferguson, G. A., \& Takane, Y. (1989). Statistical analysis in psychology and education (6th ed.). New York: McGraw-Hill.

Hill, H.C. (2010). The nature and predictors of elementary teachers' mathematical knowledge for teaching. Journal for Research in Mathematics Education, 41 (5), 513-545. doi:10.2307/41110412.

Hill, H.C., Ball, D.L., \& Schilling, S.G. (2008). Unpacking pedagogical content knowledge: conceptualizing and measuring teachers' topic-specific knowledge of students. Journal for Research in Mathematics Education, 39(4),372-400.

Hill, H.C., Rowan, B., \& Ball, D.L. (2005). Effects of teachers' mathematical knowledge on student achievement. American Educational Research Journal, 4(2), 371-406. doi: 10.3102/00028312042002371

Hooper, D., Coughlan, J., \& Mullen, M. (2008). Structural Equation Modelling: Guidelines for Determining Model Fit. Electronic Journal of Business Research Methods, 6(1), 53-60.

Jöreskog, K.G., \& Sörbom, D. (1993). LISREL 8: Structural equation modeling with the simple's command language. Lincolnwood: Scientific Software International, Inc.

Kabakçı-Yurdakul, I., Odabaşı, H.F., Kılıçer, K., Coklar, A.N., Birinci, G., \& Kurt, A.A. (2012). The development, validity and reliability of TPACK-deep: A Technological Pedagogical Content Knowledge Scale. Computers and Education, 58 (3), 964-977. doi.org/10.1016/j.compedu.2011.10.012.

Karasar, N. (2014). Bilimsel araştırma yöntemleri: kavramlar, teknikler ve ilkeler (27. Print). Ankara: Nobel Publishing.

Karp, A. (2010). Analyzing and attempting to overcome prospective teachers' difficulties during problem solving instruction. Journal of Mathematics Teacher Education, 13(2), 121-139.

Kaya, S., \& Dağ, F. (2013). Turkish Adaptation of Technological Pedagogical Content Knowledge Survey for Elementary Teachers. Educational Sciences: Theory \& Practice, 13(1), 302-306.

Kaya, Z., Kaya, O.N. \& Emre, İ. (2013). Adaptation of Technological Pedagogical Content Knowledge Scale to Turkish. Educational Sciences: Theory \& Practice, 13 (4), 2367-2375.

Kersting, N.B., \& Givvin, K.B., Thompson, B.J., Santagata, R., \& Stigler, J.W. (2012). Measuring usable knowledge teachers' analyses of mathematics classroom videos predict teaching quality and student learning. American Educational Research Journal, 49(3), 568-589. doi.org/10.3102/0002831212437853.

Kılıç Çakmak, E., Çebi, A., \& Kan, A. (2014). Developing a social presence scale for e learning environments. Educational Sciences: Theory\& Practice, 14 (2), 764-768. 
Kleickman, T., Richter, D., Kunter, M., Elsner, J., Besser, M., Krauss, S., Cheo, M., \& Baumert, J. (2015). Content Knowledge and Pedagogical Content Knowledge in Taiwanese and German mathematics teachers? Teaching and Teacher Education, 46, 115-126.

Kline, R.B. (1994). [Review of Handbook of psychological assessment, Goldstein and Herson (Eds., 1990).] Journal of Psycho Educational Assessment, 12, 180-185.

Kline, R.B. (2011). Convergence of structural equation modeling and multilevel modeling. In M. Williams \& W. P. Vogt (Eds.), Handbook of methodological innovation in social research methods (pp. 562-589). London: Sage.

Koirala, H.P., Davis, M., \& Johnson, P. (2008). Development of a performance assessment task and rubric to measure prospective secondary school mathematics teachers' pedagogical content knowledge and skills. Journal of Mathematics Teacher Education, 11, 127-138.

König, J., Blömeke, S., Klein, P., Suhl, U., Busse, A., \& Kaiser, G. (2014). Is Teachers' General Pedagogical Knowledge a premise for noticing and interpreting classroom situations? A video-based assessment approach. Teaching and Teacher Education, 38, 76-88. doi.org/10.1016/j.tate.2013.11.004.

König, J., Blömeke, S., \& Kaiser, G. (2015). Early Career Mathematics Teachers' General Pedagogical Knowledge and Skills: Do Teacher Education, Teaching Experience, and Working Conditions Make a Difference? International Journal of Science and Mathematics Education, 13; 331-350. https://doi.org/10.1007/s10763015-9618-5

König, J., Blömeke, S., Paine, L., Schmidt, W.H., Hsieh, F.J. (2011). General Pedagogical Knowledge of Future Middle School Teachers: On the Complex Ecology of Teacher Education in the United States, Germany, and Taiwan. Journal of Teacher Education, 62 (2),188-201. doi.org/10.1177/0022487110388664.

König, J., Ligtvoet, R., Klemenza, S., \& Rothland, M. (2017). Effects of opportunities to learn in teacher preparation on future teachers' general pedagogical knowledge: Analyzing program characteristics and outcomes. Studies in Educational Evaluation, 53, 122-133. doi.org/10.1016/j.stueduc.2017.03.001.

Köse, M., \& Selvi, M. (2016). A valid and reliable pedagogical content knowledge scale developing research: Example of cell divisions topic. Electronic Turkish Studies, 11 (9), 559-578. 10.7827/TurkishStudies.9508.

Nunnaly, J. (1978). Psychometric theory. New York: McGraw-Hill

Özel, M., Timur, B., Timur, S., \& Bilen, K. (2013). The adaptation of students' perceptions of college teachers' pedagogical content knowledge questionnaire into Turkish. Journal of Kırşehir Faculty of Education, 14 (1), 407-428.

Öztürk, E., \& Horzum, M.B. (2011). Teknolojik pedagojik içerik bilgisi ölçeğinin Türkçe’ye uyarlaması. Journal of Kırşehir Faculty of Education, 12 (3), 255-278.

Peers, I. (1996). Statistical analysis for education and psychology researchers: Tools for researchers in education and psychology. London: Falmer Press.

Ponte, J.P., \& Chapman, O. (2006). Mathematics teachers' knowledge and practices. In A. Gutierrez \& P. Boero (Eds.), Handbook of research on the psychology of mathematics education: Past, present and future (pp. 461-494). Roterdham: Sense Publishers.

Sánchez, M. (2011). A review of research trends in mathematics teacher education. PNA, 5(4), 129-145.

Schermelleh-Engel, K., Moosbrugger, H., \& Müller, H. (2003). Evaluating the fit of structural equation models: Tests of significance and descriptive goodness-of- fit measures. Methods of psychological research Pedagog_cal knowledge and sk_ll, 8(2), 23-74.

Seçer, İ. (2015). SPSS ve Lisrel ile pratik veri analizi: Analiz ve raporlaştırma. Ankara: Anı Publishing.

Schumacher, R.E., \& Lomax, R.G. (1996). A beginner's guide to SEM. New Jersey: Mahwah.

Shulman, L.S. (1986). Those who understand: Knowledge growth in teaching. Educational Researcher, $15(2), 4$ 14.

Shulman, L.S. (1987). Knowledge and the Teaching: Foundations of the new reform. Harvard Educational Review, 57, 1-22. doi.org/10.17763/haer.57.1.j463w79r56455411.

Sivacı, S.Y. (2017). Examining Primary Education Senior Students' Field Knowledge Competence and Attitudes Towards Mathematic: A Comparative Research. International Journal of Eurasia Social Sciences, 8(26), 244-255.

Silverman, J., \& Thompson, P.W. (2008). Toward a framework for the development of mathematical knowledge for teaching. Journal of Mathematics Teacher Education, 11 (6), 499-511.

Sümer, N. (2000). Yapısal eşitlik modelleri: Temel kavramlar ve örnek uygulamalar. Türk Psikoloji Yazlları, 3(6), 49-74.

Şahin, İ. (2011). Development of survey of technological pedagogical and content knowledge (TPACK). Turkish Online Journal of Educational Technology, 10 (1), 97-105.

Tabachnick, B.G., \& Fidell, L.S. (2007). Multivariate analysis of variance and covariance. Using multivariate statistics, 3, 402-407. 
Tatto, M.T., Schwille, J., Senk, S., Ingvarson, L., Peck, R., \& Rowley, G. (2008). Teacher Education and Development Study in Mathematics (TEDS-M): Conceptual framework. East Lansing: Michigan State University

Tavşanc1l, E. (2014). Tutumların ölçülmesi ve spss ile veri analizi. Ankara: Nobel Publishing.

Tezbaşaran, A. A. (1996). Likert tipi ölcek gelistirme kılavuzu [Guide for Likert type scale development]. Ankara: Türk Psikologlar Derneği.

Thompson, B. (2004). Exploratory and confirmatory factor analysis: Understanding concepts and applications. American Psychological Association.

Timur, B., \& Taşar, M.F. (2011). The Adaptation of the Technological Pedagogical Content Knowledge Confidence Survey into Turkish. Gaziantep University Social Sciences Journal, 10 (2), 839-856.

Wong, A. F. L., Chong, S., Choy, D., Wong, I. Y-F., \& Goh, K. C. (2008). A comparison of perceptions of knowledge and skills held by primary and secondary teachers: from the entry to exit of their preservice program. Australian Journal of Teacher Education, 33(3), 77-93. doi.org/10.14221/ajte.2008v33n3.6.

Wong, A., Chong, S., Choy, D., \& Lim, K.M. (2012). Investigating changes in pedagogical knowledge and skills from pre-service to the initial year of teaching. Educational Research for Policy and Practice, 11,105-117. Doi:10.1007/s10671-011-9108-7

Yılmaz, Z., \& Haser, Ç. (2018). Pre-Service teachers' restructuring of mathematical content knowledge in a learning trajectories based instruction. Elementary Education Online, 17 (1), 187-206. 


\section{APPENDIX 1. Pedagogical Knowledge and Skills Survey in Turkish}

\section{Pedagojik Bilgi ve Beceri Anketi}

1. Öğretim sırasında öğrencilerin öğrenmeye olan ilgilerini artırırım.

2. Kendi konu alanıma öğrencilerin ilgisini çekerim.

3. Derslerimde yeri geldikçe eleştirel düşünmeye yer veririm.

4. Derslerimde yeri geldikçe yaratıcı düşünmeye yer veririm.

5. Öğrenciler arasında düşünmeyi özendirir ve bu konuda gereken kolaylığı sağlarım.

6. Öğrenci merkezli öğrenme ve öğretme etkinlikleri kullanırım.

7. Öğrencileri çok çalışmaları için motive ederim.

8. Öğrettiğim konuya uygun öğretim yöntemlerini seçerim.

9. Öğrencilerin farklı yetenek seviyeleriyle uyuşacak öğretim yöntemleri seçerim.

10. Öğrencilere öğrenmelerini kolaylaştırmak için uygun sorular sorarım.

11. Öğretim içeriğini-müfredatı derslere bölerek işlerim.

12. Öğrencilerin farklı yeteneklerini dikkate alarak derslerimi planlarım.

13. Dersin içeriğine uygun öğretim yöntemlerini belirlerim.

14. Derslerimi öğrenci merkezli olarak hazırlarım.

15. Kendi öğretim materyallerimi hazırlayabilirim.

16. erslerim için uygun öğretim materyalleri edinirim.

17. Derslerimde öğretim teknolojilerinden en etkili şekilde yararlanırım.

18. lçme-Değerlendirme araçlarımı (yazılı sınavlar, sözlü sınavlar, testler vb.) hazırlarım.

19. Öğretim boyunca uygun değerlendirme formlarını kullanırım.

20. Öğretimim için içerikle ilgili konuları içeren kaynaklar edinirim.

21. Öğrencilerimin gelişimlerine yardımcı olmak için değerlendirme amaçlı dönütler veririm.

22. Öğrencilerin öğrenme hızına göre öğretimimi gerçekleştiririm.

23. Öğrencilerimin öğrenme güçlüklerini tespit ederim.

24. Öğrencilerin farklı ihtiyaçlarına hassasiyetle karşılık veririm.

25. Öğrencilerin grup çalışmalarını etkili biçimde kontrol ederim.

26. Öğrencilerin bireysel öğrenmelerini etkili biçimde kontrol ederim.

27. Ders sırasında öğrencilerin öğrenme ve performanslarını gözlemlerim.

28. Ders içinde uygun sınıf yönetimi tekniklerini kullanırım.

29. Davranış ve öğrenme problemi olan öğrencileri kontrol ederim.

30. Öğrenci davranışlarını gözlemlemek için uygun stratejiler kullanırım.

31. Öğrencileri disipline ederim.

32. Müfredata yardımcı etkinlikler düzenlerim.

33. Zamanı etkili şekilde kullanırım.

34. Güçlüklerle başa çıkma becerisine sahibimdir.

35. Stresle başa çıkarım.

36. Öğrencilerimin her açıdan gelişimi için gerekli ilgiyi gösteririm.

37. Öğrencilerime her konuda gerekli ilgi ve özeni gösteririm. 


\section{TÜRKÇE GENIŞLETILMIŞ ÖZET}

Öğretmen yeterliliği, içerik bilgisi (CK), pedagojik içerik bilgisi (PCK) ve genel pedagojik bilginin (GPK) yanı sıra algılama, yorumlama ve karar verme becerilerinden oluşan çok boyutlu bir yapı olarak kabul edilir (König, Blömeke \& Kaiser, 2015). Pedagojik bilgi, öğretme bilgisi olarak öğretmen etkililiği için bir koşul olarak içeriğin nasıl öğretileceğini bilmeyi içerir (Hill, Rowan \& Ball, 2005). Pedagojik bilgi ve beceri, öğrenmenin gerçekleşmesini sağlayan öğretimsel teknikler ve stratejilerle ilgilidir ve öğretmenleri öğrenmeyi kolaylaştırıcıların, koçların, modellerin, değerlendiricilerin, yöneticilerin ve savunucuların rollerini üstlenmeye teşvik eder.

Son yıllarda öğretmen adayları ve göreve yeni başlayan öğretmenlerin pedagojik bilgi ve becerilerini değerlendiren ölçme araçları geliştiren araştırmalar yapılmaktadır. Bunlardan Chong, Choy ve Wong (2008) hizmet öncesi eğitim programlarının giriş ve çıkışında, Singapurda Eğitimde Yüksek Lisans Diploması programındaki öğretmen adaylarının öğretmenlik alanındaki pedagojik bilgi ve beceri algılarını incelemişlerdir. Kullanılan ölçme aracı, beş faktörlü 34 maddeye sahiptir. Bunlar Kolaylaştırma; Değerlendirme; Yönetim; Hazırlık ve Bakım ve Endişe'dir. Bu araştırmayı Choy, Chong, Wong ve Wong'ın (2011) bir başka çalışması izlemiştir. Yazarlar kariyerlerinin başındaki öğretmenlerin, bir yıllık hazırlık programının sonunnda ve bir yıllık öğretimlerinden sonraki pedagojik bilgi ve becerilerine ilişkin algılarındaki değiş̧iklikleri araştırmışlardır. Anketin orjinaji 50 maddeden oluşmakla birlikte araştırma amacı doğrultusunda yalnızca 38 maddeye verilen cevaplar analize dahil edilmiştir. Faktor analizi sonucunda 38 maddelik anketin 6 faktörden oluştuğu görülmüş ve anketten 4 madde çıkarılmıştır. Ortaya çıkan faktörler sırasıyla "Öğrenci Öğrenimi; Dersi Planlama; Öğretim Desteği, Çeşitliliğe Alışma; Sınıf Yönetimi ve Öğretim Dışı Görevler"dir. Bu araştırmadan sonra Choy, Lim, Chong ve Wong (2012) doğrulayıcı faktör analizi kullanarak Öğretimde Pedagojik Bilgi ve Beceri Alg1sı (Perceptions of Knowledge and Skills in Teaching: PKST) anketinin faktör geçerliliğini sunmuşlardır. Araştırmacılar, PKST'nin boyutluluğuna dair bir bakış açısı elde edebilmek için daha önceki bir veri setindeki açımlayıcı faktör analizini (AFA) kullanmışlardır (Wong, Chong, Choy, Wong, \& Goh, 2008). AFA'dan çıkarılan boyutlarla, faktör modelini çapraz doğrulamak için sonraki veri setlerinde doğrulayıcı faktör analizi (DFA) yapılmıştır. Bununla birlikte, değişiklik göstergelerine daha yakından bakıldığında, Öğrenci Öğreniminde 7. madde ile Bakım ve Endişe boyutundaki 6. madde arasında güçlü bir kovaryans olduğu görülmüş ve araştırmacılar model uyumunu iyileştirmek için SL7 nolu maddeyi ölçekten çıkarmışlardır. Aynı yıl Wong, Chong, Choy ve Lim (2012), 38 maddelik 6 faktörlü PKST anketini kullanarak Singapur Ulusal Eğitim Enstitüsü'nün Yüksek Lisans Diploması programına kayıtlı olan öğretmen adaylarının pedagojik bilgi ve beceri algılarını değerlendirmiştir.

Literatürden anlaşıldığı gibi öğretmen eğitimi programlarına devam eden veya mezun olup göreve başlayan öğretmenlerin pedagojik bilgi ve becerilerini kapsamlı bir şekilde ölçen bir ölçme aracı geliştiren Wong, vd. (2012) Singapur'daki öğretmen adayları ve görevlerinin ilk üç yılında olan öğretmenlere geliştirdikleri ölçeği uygulamışlardır. Ülkemizde ise son yıllarda öğretmen adayları ve öğretmenlerle yapılan araştırmalarda PCK (pedagogical content knowledge) (Bukova-Güzel., vd., 2013; Köse \& Selvi, 2016; Özel, vd., 2013) ve özellikle de TPCK (technological pedagogical content knowledge) (Aydeniz \& Kirbulut, 2014; Balçın \& Ergün, 2016; Canbazoğlu-Bilici, vd.,2013; Kabakç1Yurdakul, vd., 2012; Kaya \& Dağ, 2013; Kaya, Kaya \& Emre, 2013; Öztürk \& Horzum, 2011; Şahin, 2011; Timur \& Taşar, 2011) bilgilerinin ölçümüne yönelik olarak ölçek uyarlama ve geliştirme araştırmaları yapılsa da genel pedagojik bilgi ve becerileri ölçen araçların eksikliği göze çarpmaktadır. $\mathrm{Bu}$ nedenle, mevcut çalışma söz konusu ihtiyacı karşılamak üzere Wong, vd. (2012) tarafindan geliştirilen PKST'nin ülkemizde kullanılması için uyarlanması amacıyla yürütülmüştür.

38 madde ve 6 faktörden oluşan “Pedagojik Bilgi ve Beceri” ölçeğinin Türkçe’ye uyarlanması amacıyla sorumlu yazar olan Dorish Choy \& Angela F.L.'den gerekli izin alınmıştır. Ölçme aracının dil geçerliği için Brislin (1986) tarafından önerilen standart çeviri-geri çeviri yöntemi kullanılmıştır. Maddeler 
İngilizceden Türkçeye, sonrasında Türkçe'den İngilizce'ye çevrilmiştir. Çevrilen maddeler birbirleriyle karşılaştırılmıştır. Farklı olan maddeler tekrar İngilizceye çevirilerek original ölçeğe en yakın çeviriler belirlenerek Türkçe deneme formu oluşturulmuştur. Oluşturulan deneme formu iki farklı üniversitenin (Kırıkkale Üniversitesi ve Karadeniz Teknik Üniversitesi) farklı öğretmenlik bölümlerindeki (Fen Bilgisi, Sosyal Bilgiler, İlköğretim Matematik, Beden Eğitimi ve Ortaöğretim Matematik) iki farkl1 gruba uygulanmıştır. Birinci grup (110'u kadın ve 95'i erkek) toplam 205 öğretmen adayından oluşmuştur. Bu çalışma grubu üzerinde Açımlayıcı Faktör Analizi (AFA) yapılmıştır. İkinci çalışma grubuna (330’u kadın ve 295'i erkek) toplam 625 öğretmen adayı dahil edilmiştir. Çalışma toplam 830 ögretmen adayı üzerinde gerçekleştirilmiştir.

Veriler elde edildikten sonra cevaplamada herhangi bir hata ve eksik bulunan kağıtlar çıkartılmış, veriler böylece değerlendirmeye alınmıştır. Bu amaçla ilk olarak madde analizleri (Madde toplam test korelasyonu ve \%27 alt-üst grup karşılatırması) gerçekleştirilmiştir. Ardından yapı geçerliği için analizler uygulanmıştır. Bu amaçla ilk olarak aynı yapıyı ölçen değişkenleri (maddeleri) bir araya toplayarak daha az sayıda değişken ile açıklamayı amaçlayan istatistiksel teknik olan Açımlayıcı Faktör Analizi (AFA) kullanılmıştır. Altı boyut ve 37 maddeden oluşan bir yapı tespit edilmiştir. Bu yapı orjinal ölçek ile benzer göstermekte olup, sadece ölçeğin 3. boyutunda yer alan 19. maddenin madde faktör yük değerinin düşük olması ve birden fazla faktöre yük vermesinden (binişik olması) dolayı ölçekten çıkartılmıştır. Ölçekte yer alan madde faktör yük değerleri 0.39 ile 0.81 arasında yer almaktadır. Ölçeğin birinci boyutunda bu değerler 0.55 ile 0.78 arasındadır. Ikinci boyutta 0.47 ile 0.75 arasında değerler almaktadır. Üçüncü boyuttaki madde faktör yük değerleri 0.48 ile 0.76 arasında değerleri içermektedir. Ölçeğin dördüncü boyutuna ise bu değerler 0.39 ile 0.69 arasındadır. Beşinci boyutta yer alan madde faktör yük değerleri 0.45 ile 0.71 arasındadır. Ölçeğin son boyutundaki madde faktör yük değerleri 0.50 ile 0.74 arasındadır. Bir çok araştırmacıya göre madde faktör yük değerinin 0.30 'dan yüksek olması gerekmektedir (De Vellis, 2014; Seçer, 2013; Tavşanc1l, 2014). Mevcut bulgular dikkate alınırsa, ölçekte yer alan maddelerin mevcut faktörleri açıklama düzeyinin iyi olduğu söylenebilir. Ardından mevcut yapının farklı örneklem ya da farklı kültürel yapıda benzer yapıyı gösterip göstermediğini test etmek amacıyla Doğrulayıcı Faktör Analizi (DFA) yapılmıştır. Elde edilen fit indeks değerleri $(\mathrm{x} 2 / \mathrm{sd}=3.00, \mathrm{RMSEA}=0.056, \mathrm{PGFI}=0.75, \mathrm{GFI}=0.87, \mathrm{AGFI}=0.85, \mathrm{PNFI}=0.89, \mathrm{IFI}=0.98, \mathrm{NFI}=0.97$ ve $\mathrm{CFI}=0.98$ ) altı boyuttan oluşan yapının Türkçeye uyduğunu göstermiştir. Ölçme aracının güvenirliğine yönelik olarak Cronbach Alpha katsayısı hesaplanmıştır. Bu değer ölçeğin geneli için 0.94'tür. Ölçeğin alt boyutları için güvenirlik değerleri ise 0.70 ile 0.88 arasında bulunmuştur. Bu değerler ölçme aracının güvenilir ölçüm yaptığını göstermektedir. Ölçme aracının geneli ve alt boyutları arasındaki ilişkinin de yüksek olduğu ve bu değerlerin 0.79 ile 0.87 arasında değiştiği saptanmıştır.

Sonuç olarak, yapılan geçerlik ve güvenirlik analizleri doğrultusunda; PKST ölçeği için 6 boyut ve 37 maddeden oluşan bir yapı elde edilmiştir. Bu ölçme arac1 5'li likert tipinde olup, ölçekten alınabilecek en düşük ve en yüksek puanlar sırasıyla 37 ile $185^{\prime}$ tir. Ölçme aracının tüm maddeleri olumlu olup, tersten puanlanması gereken madde bulunmamaktadır. Analizler sonucunda elde edilen bulgular dikkate alındığında; "Pedagojik Bilgi ve Beceri" ölçeğinin Türk kültürüne uygun bir ölçme aracı olduğu söylenebilir. 